\author{
Katarzyna Doliwa \\ University of Białystok \\ e-mail: kdoliwa@uwb.edu.pl \\ ORCID: 0000-0001-8583-8379
}

\title{
THE CONCEPT AND FUNCTIONS OF A UNIVERSAL LANGUAGE OF LAW
}

\begin{abstract}
The subject of the article is the concept of a universal language and a reflection on its importance for law. The starting point is a presentation of the history of the concept of a common language for all mankind, a concept that has always accompanied man - it is present in the Bible, in the ancient writings of Near Eastern peoples, it was alive in the Middle Ages and during the Renaissance, and it experienced its particular heyday - among other reasons because of the gradual abandonment of Latin as the language of science - in the seventeenth century, an age that was reformist by definition. Since its inception, the concept of a universal language has been inextricably linked with the idea of world peace and universal happiness for all people. It is significant that in most universal language designs, regardless of the era, there were, to a greater or lesser extent, references to the utility of such languages for law. The author, tracing the development of the concept of a universal language, focuses on its fullest contemporary development: Esperanto. Esperanto, like previous universal language designs, places particular emphasis on ideas linked to the concept of a universal language, especially the idea of peaceful coexistence and understanding between peoples. In this context, it is reasonable to ask what role Esperanto can play in the development of certain branches of law, especially international law. Given the position of English as the language of legal acts of international importance, the answer to this question is currently not clear.
\end{abstract}

Keywords: universal language, language of law, Esperanto, Ludwik Zamenhof.

\section{Introduction. Subject, scope, and purpose of the study}

The subject of this article is the idea of a universal language and analysis of its importance for law. The research was conducted by the method of analysing the pertinent literature from a historical and functional perspective. The literature on various concepts of universal languages, the language of law, and legal linguistics is examined here. The statutes of the Esperanto 
Lawyers Association are analysed, as well as selected issues of a legal periodical in Esperanto. The aim of the study of the idea of a universal language, taking Esperanto as an example, is to show its significance for law - in the sphere of its creation and application - especially in relation to international law. The aim is to show that by expressing legal norms (rules of conduct in social relations) in a universal language (e.g. Esperanto), by emphasizing through its features the basic functions of language (cognitive, social, and affective), it would be more possible to realise the idea of world peace and universal happiness for mankind and to develop international law.

The idea to create a universal language that would be a tool for understanding and peaceful cooperation between nations is not a modern invention: such designs were proposed as early as in Antiquity, were present in the Middle Ages, and were particularly abundant in the 17th century. Since the Enlightenment, there have been nearly six hundred universal language designs, with different purposes and varying degrees of sophistication. Among the multitude of universal languages, Esperanto is the only one that has gained global renown and a large group of loyal followers, and has survived for over a century. The community of Esperantists has formed an internally diverse, content-rich, and widespread social movement whose members and enthusiasts can be counted in the millions since the inception of the language (Grzybowski, 2017). Today, the language is spoken to a greater or lesser degree by two million people worldwide, and the Esperantist community is strongly integrated. Esperanto is the only universal language that has proven its value in practice, as the tangible and intangible cultural artefacts associated with it amply attest. As the only universal language, it has the potential to achieve the main goals that have been set for centuries for universal language designs: to ensure peace and prosperity for societies and to enable the cooperation that contributes to human progress. Many of these goals can be pursued through international law, and thus the question of using Esperanto as a universal language of law is legitimate.

\section{On the concept of universal language}

It is possible that a language common to all people existed in the distant history of the human species; the science of linguistics has a monogenetic hypothesis that all languages of the world have their common origin in one primordial language and when our ancestors migrated, this language be- 
gan to diversify, forming dialects at first and different languages later. This concept appears not only in science, but also in myths and legends about a common language, such as the biblical myth of the Tower of Babel, which describes the loss of a common language, resulting in an inability to communicate and the abandonment of cooperation among people (an alternative to the aforementioned hypothesis is the more popular polygenetic hypothesis, which assumes that language developed in several places on Earth) (Jurkowski, 1986). A longing for a universal language that ensures not only perfect understanding of other people but also peace and universal happiness is found in many religions. The ancient Persians assumed that people that speak different languages and are in conflict would in the future get "the kingdom of Ormuzd and then the people would be happy, the whole Earth would become one country, and there would be only one language, one law for all, and one government" (translation mine) (Jurkowski, 1986, p. 15). It is significant that as early as in antiquity the concept of a universal language was accompanied by the concepts of universal law and happiness for all people.

An interesting design for a universal language was presented by Claudius Galen, a famous physician who lived in antiquity and a great authority for medieval scholars. His work on a universal language, known only from the account of the Roman historian Pison, was inspired by Plato's statement that the greatest gift of the gods to men would be a common language. Galen's concept, one of the first designs in pasigraphy, or universal writing, met with widespread resonance among his contemporaries (Jurkowski, 1986). In the Middle Ages, philosopher Ramon Llull, the designer of a logical machine, developed a design for universal writing, based on the method of conversation he created, which used dialectics and logic. His proposal was reminiscent of the philosophical languages that were created later based on the logical division of concepts. Llull had many followers during the Renaissance: Giordano Bruno and Nostradamus supported designing a logical language common to all people. Teofilo Folengo, an Italian poet who lived in the Renaissance period, was the first to propose a universal language not only for writing and reading, but also for speaking; his concept was close to Esperanto and was a kind of grammatically simplified Latin. The fear of the disappearance of Latin as a language of science and the hope for a future universal language was expressed by the Spanish humanist Juan Luis Vives: "It would be fortunate if there were a single language that all nations could use. Latin will perish and then there will be confusion and discord in all sciences, danger, and universal alienation among men" (translation mine) (Jurkowski, 1986, pp. 18-19). 


\section{Seventeenth-century universal language designs}

In the 17th century Vives' fears become reality: Latin lost its status as the international language of science; more and more authors wrote in national languages (Descartes' revolutionary "Discourse on Method" was written in French). It was then that the limitations to the circulation of information in science were clearly realized and it was understood that the lack of a common language could become a barrier to the development of science and thus to the progress of human thought. Therefore, the seventeenth century is characterized by numerous attempts to create universal languages and grammars - H. Święczkowska (1998) calls this period the era of universal language designs. Providing a medium to make scientific achievements known to all was not the only goal of thinkers interested in the design of a universal language. The reform and unification of the language was to be the remedy for all the misfortunes of Europe at that time; the saving power of a common language was commonly believed in (Janton, 1993). The multiplicity of "one language" designs emerging at the time is in keeping with the tendency toward reforms, which was typical of that era. Almost all the old systems - economic, political, and scientific - were thoroughly rebuilt at that time and the language at the heart of them had to be reconstructed as well. Attempts to find a universal language were made at that time in various ways: some thinkers compared languages to find the most perfect one, others considered simplifying one of them as much as possible, and still others made plans to create a universal language from scratch (Święczkowska, 1998).

One of the designers of a universal language was Francis Bacon. His proposition was to create a universal perfect language based on philosophical grammar. The method adopted by Bacon consisted in comparing the grammars of modern natural languages, taking their best elements, and combining them into one coherent linguistic system (Heinz, 1978). The author himself recognized the disadvantages of his idea: he realized that mastering the complex grammar of such a language, as well as its vocabulary, would be a difficult task. Bacon's concept, however, found numerous imitators, with the most advanced design proposed by Cave Beck in his work entitled "The Universal Character, by which all Nations in the World may understand one another's Conceptions" (Stillman, 1995, Święczkowska, 2002).

Descartes, the most prominent seventeenth-century philosopher, also commented on the concept of natural language. His comments were prompted by a pamphlet published in Paris in 1629, the author of which set out in Latin, in six points, his assumptions about the structure, func- 
tion, and use of a universal language (interestingly, similar assumptions were made by the creator of Esperanto more than two centuries later). The proposed language was to be a quasi-natural language used both in speech and writing. Its grammar was to be so easy that the average person would be able to build sentences in it with the help of a dictionary after just five or six hours (Janton, 1993). The language would also be the basis for learning other languages, which would be treated as its dialects. The anonymous author did not decide whether it was to be an entirely new linguistic system, a system based on existing natural languages, or a system resulting from numerous simplifications of the vocabulary and grammar of a language group. Descartes was convinced that creating a universal language that resembles natural languages and is different from them in terms of simplicity was possible, but in his opinion, mastering the vocabulary of such a language would be as difficult as memorizing the vocabulary of a natural language. Descartes' opinion of this particular design was critical, but he also supported the very idea of a universal language. According to the author of the "Discourse on Method," an ideal universal language should be based on universal grammar, its vocabulary should have no ambiguous words, and each lexeme should have the rank of a scientific term. The basis of such a language should be a transparent principle, e.g. one analogous to the principle of construction of a sequence of numbers; indicating such a principle would be possible by defining the order of all the thoughts that the human mind can accommodate (Kopania, 1988, Okrent, 2009). The basic condition for creating a universal language is having an adequate philosophical system:

(...) the invention of such a language depends on true philosophy; for without it, it is impossible to enumerate and order all human thoughts, or even merely to distinguish them, so that they become clear and simple (...). And if someone would correctly explain what the simple ideas contained in the imagination of men are, of which everything that men think is composed, if, moreover, this explanation were universally recognized, then I would hope for emergence of a universal language that is very easy to learn in speech as well as in writing, and, most importantly, one that would aid our judgment by presenting everything to it so clearly that it would be almost impossible to be wrong (translation mine) (Kopania 1988, pp. 199-200).

The Cartesian version of a universal language, based on a coherent philosophical system, was supposed to bring people a valuable benefit: it was to protect them from making errors in their reasoning.

Another seventeenth-century thinker passionately committed to the idea of creating a universal language was Gottfried Wilhelm Leibniz. Al- 
though Leibniz devoted himself to this idea from the beginning of his writing and his name appears frequently in discussions on a universal language, the scholar never succeeded in finalizing his project, which never went beyond the stage of sketches and preliminary assumptions (Święczkowska, 1998). Leibniz's aim was to create a language that would reproduce the laws of pure thought free from the influence of natural languages. Convinced about the power of the mathematical method, the German philosopher stressed that the new language should be similar to the language of arithmetic, an idea clearly stated in the title of his work, which contained this concept: "Conceptual writing - a symbolic, arithmetically formed language of pure thinking" (Begriffsschrift - eine der arithmetischen nachgebildete Formelsprache des reinen Denekens) (Marciszewski, 2002). Leibniz attributed to every simple thought, every idea, a specific sign, which is a symbol of a specific meaning, while allowing for the possibility that this symbol could be read differently in each language - after all, this would be the language of thoughts, not words. If every simple idea were labeled with a symbol, they could be manipulated like the signs in algebraic operations and thus every thought could be expressed in an ambiguity-free, strict and precise manner. ${ }^{1}$ Included in this concept is the firm belief that human thinking can be formalized and captured in the form of an algorithm (Święczkowska, 2016).

Philosophers of the seventeenth century called for the renewal of language because it was an indispensable element in the construction of the new science - the renewed language was to become its effective tool, helping to remove all scholastic remnants from the system of knowledge. The slogan of language reform also grew out of the then widespread conviction that the peculiar seventeenth-century "confusion of languages," the new Tower of Babel, or linguistic pluralism, was responsible for confusion and social unrest. Language issues arose in the midst of heated political disputes; it was hoped that solutions to language issues would help in finding ways out of the impasse on social issues. Importantly, seventeenth-century thinkers universally assumed pan-sophism; they believed that science was a universal system of which law and other social sciences were an important part. A new science and a new perfect language, perhaps based on logic, was to bring benefits to law as well. Scholars of the era also saw an opportunity to quell social unrest in the reform of legal systems (Stillman, 1995).

It was Leibniz who was the founder of such a universal system and an author who was fully aware of the scientific revolution that was taking place in his time. The German scientist was convinced that the changes brought about by contemporary natural science must inevitably have an impact on 
human sciences and contribute to their thorough renewal. He advocated restoration of the unity of human cognition, restoration of the immanent link between physical and moral sciences. Leibniz's pansophical works include the "Nova methodus discendi docendaeque Jurisprudentiae," where considerations of jurisprudence are preceded by a presentation of the system of knowledge, with an indication of the place of each branch of science, established precisely according to a "specific mnemonic, encyclopaedic, and rational function." The new science of the principles of justice could be as rigorous as Euclidean geometry. The German scholar was certain that the study of jurisprudence required knowledge of philosophical ideas. In his opinion, essential to the study of law was also logical knowledge, a universal method allowing one to read a kind of "alphabet of the world" (Vasoli, 1996).

The seventeenth century was exceptional when it comes to the number of designs of a universal language, but there was no shortage of them in the century that followed. This concept attracted French encyclopaedists; the ninth volume of the "Great French Encyclopedia" included the entry "La langue nouvelle," which presented a plan for a universal language: a simplified version of French. The author of the entry, Joachim Faiguet de Villeneuve, suggested that the design of an international language should be adopted and approved by European academies of sciences. Voltaire, Monteskius, and Condillac also spoke in a similar vein (Jurkowski, 1986).

\section{Origin and aims of Esperanto}

The greatest achievement in the search for an international universal language is Esperanto, a language that has overshadowed all other proposals, including those made later, in the 20th century. According to Zenon Klemensiewicz (1963), of all other proposals, Esperanto is:

the most successful and the most widely used. The very need for such an international means of communication is proven by the fact that different national languages, living and dead, have fulfilled this function at certain times. But one may think that an artificial language is up to the task because it can be made as easy as possible and thus also the most suitable for mass use (translation mine).

Esperanto (in that language, the word "esperanto" means "hopeful") was created in 1878 and, unlike national languages, was intended to be neutral and easy to learn, so that it could function as a second language, taught alongside the national language and used in situations that require 
understanding between peoples and their representatives. Its grammar can be summed up in a dozen or so rules, its syntax is uncomplicated, and its vocabulary comes from Romance languages (60\%), Germanic languages (30\%), and Slavic languages (10\%). Esperanto can easily distinguish the basic parts of speech - all nouns end with "o", adjectives with "a", adverbs with "e", and the infinitive verb ends with " $\mathrm{i}$ ". It is likewise easy to distinguish one of the three tenses - the verb in the present tense ends with "as", in the past tense - with "is", in the future tense - with "os", and for each person and number of any tense there is only one form, preceded by an appropriate pronoun. Importantly, Esperanto has word-formation potential, which allows for its evolution and the gradual enrichment of its dictionary; Zamenhof's first dictionary consisted of 4,444 words, today the Esperanto dictionary includes over 100,000 words. One of the ways to build new words is to combine words that already exist in the language - in this way, words consisting of several morphemes can be created; the second way of enriching Esperanto with new words, willingly used by Zamenhof himself, is to import whole words from European languages (the author of Esperanto preferred words that had come into common international use) (Forster, 2012).

The atmosphere and uniqueness of 19th-century multicultural Białystok, where its creator Ludwik Zamenhof grew up, contributed to the creation of Esperanto. While living in Białystok's Tower of Babel, Zamenhof set out to create the foundations of an international language, the basic aim of which was to find a recipe for avoiding conflicts between people of different nationalities and religions (Jurkowski, 1986).

Although Esperanto was designed as a world language, in its first years it was more of a European language: the first Esperanto world congresses were held in Europe and this is where the organizations that promoted Esperanto were based (Żytyński, 1987). In the following decades of its existence, the language not only strengthened its position throughout Europe, but also reached Asia and America. In 1905, the First World Congress of Esperantists was held in Boulogne-sur-Mer, France, which energized its supporters and opponents (Sygnarski, 1963). The annual Esperanto conventions have played a great role in strengthening and spreading the concept of Esperanto. The organization of the Congresses was interrupted by the outbreak of World War I - a painful blow to the concept of Esperanto and to Zamenhof himself, who made repeated appeals for peace and understanding between nations, and even dreamt that "people would one day melt into one nation" (Romaniuk, Wiśniewski, 2009).

After the war, during the 10th Congress in Paris, Zamenhof proclaimed the principle of reconciliation of nations, stating that each state should 
fully belong to its citizens, both materially and spiritually. On 10 December 1954, at the 8th General Session of UNESCO in Montevideo, a resolution was passed that significantly influenced the development and position of Esperanto. The resolution acknowledged the merits of the language in spreading cultural heritage, especially in developing countries, and highlighted Esperanto's achievements in maintaining international cultural ties and bringing nations together (Jurkowski, 1986). A similar declaration was adopted on 8 November 1985 in Sofia. Alongside the recognition of Esperanto's success in the field of international cultural exchange, UNESCO "called on member states to encourage the inclusion of language problems and Esperanto in school and university curricula" and requested examining the possibility of using Esperanto to convey all kinds of information among its members, including information on UNESCO's activities (Draft resolution on establishing 2017 as the Year of Ludwik Zamenhof - the creator of the Esperanto language, 2016).

A testimony to Esperanto's worldwide success and proof of its potential as a means of communication of cultural values and assets was the publication in Esperanto of Eugene Aisberg's popularizing work entitled "Radio - it's so simple!" It was published in episodes in the Esperanto magazine "Internacia Radio-Revuo" and then translated into Czech and twenty other languages. In 1934, its book edition in Esperanto was published in Budapest. By serving as a bridge language, Esperanto has certainly helped to popularize masterpieces of world literature. It is also used for translation in various fields of science and public life. The potential of Esperanto in the field of education should also be recognized, as the language is used by educators for teaching purposes and for international exchanges. Esperanto is taught at various stages of education, including higher education, in Europe and on other continents (Grzybowski, 2017). Esperantists are distinguished by their tendency to associate, forming national associations in most countries of the world, on all continents, as well as subject-specific associations that bring together hobbyists and adherents of a particular worldview, ideology, profession, or religion (Krzyżak, 2011).

\section{Esperanto as the universal language of law?}

Esperanto works as a language of culture: it is used to produce original literary texts and translations from natural languages, it is the language of the press, theatre productions, and films, and it is used in music, in internet reporting, and for radio and television programs. Esperanto 
is often used in international correspondence, at international conferences, congresses and discussions. Last but not least, Esperanto is the language of education - in this context, it is reasonable to ask what role Esperanto could play in law.

The answer to the above question must take into account the specific nature of the language of law. It is certainly not a homogeneous phenomenon that can be easily classified and investigated; some researchers of the language of law consider it to be a special type of specialist language that should be distinguished within the national language. The literature also emphasizes its location between artificial and natural languages (Woleński, 1967). It seems that the language of law meets the criteria of a specialized language as a subsystem of a general language - being a special form of the national language, it is used to precisely describe a specific field of knowledge. The language of law is seen as the technical language of a particular professional group, but at the same time it is a characteristic of this technical language that it is used not only by the professional group itself for intra-group communication, but also for communication with persons outside the professional group and even sometimes by those persons themselves when they intend to perform legal acts without direct reference to members of the professional group. It's important that legal language isn't an instrument aimed solely at internal communication within the legal profession. It is a language whose use is widespread, governs all areas of social life and influences ordinary language (Mattila, 2006). Mellinkoff defines the English language of law as follows:

Language of law is the customary language used by lawyers in those common law jurisdictions where English is the official language. It includes distinctive words, meanings, phrases, and modes of expression. It also includes certain mannerisms of composition not exclusive with the profession but prevalent enough to have formed a fixed association (2004, p. 3).

The language of law grows out of the ethnic language - it has taken over its phonetics, syntax, and general vocabulary (Mattila, 2012, 2006). Such a solution is conditioned by the social function of law - in order to be able to reach individual members of society, the law must be communicative, the legislature and commentators of law cannot use completely hermetic language. Although the language of law draws abundantly from the national language, the differences between it and the national language are noticeable. These differences relate to vocabulary, terminology, and sometimes specific stylistics. The differences related to lexis are of a various nature. First, in the language of law, there are phrases and expressions not present 
in the ethnic language. Secondly, certain terms and expressions of the national language are given a special meaning by law - sometimes radically different from the meaning in the national language, sometimes broader or narrower than it (Matulewska, 2008, Mattila, 2012). Moreover, in the language of law, there are words that belong to the ethnic language, but the meaning they acquire in the law is precise and clear (Mellinkoff, 2004).

Another way of enriching legal language is by borrowing from a foreign legal language or by introducing neologisms. For a century, the most important source of borrowing in Western legal languages was Latin; all legal languages of Europe contain a large number of borrowings from Latin. In the eighteenth and nineteenth centuries - the time of the dominance of French legal culture and French legal language - European legal languages adopted French expressions, both as direct borrowings and as word calques. In turn, the influence of German legal language in the late nineteenth and early twentieth centuries was more limited, with naturalisation of German words and less direct borrowing. Today, European languages draw the largest number of borrowings from English and these are mostly direct borrowings (Mattila, 2012). Another determinant of legal language is the presence of neologisms in it: they are especially frequent in EU legislation and based on French and English. The introduction of numerous neologisms is intended to avoid confusion between the different meanings of the same legal term adopted in the Member States. "... one may say that the European Union is the most important factory of legal and administrative neologisms in the Western Europe" (Mattila, 2012, p. 36).

As H. E. S. Mattila points out, legal terminology is characterised by polysemy. Even within one legal culture, the same term can refer to several different legal concepts, depending on the context in which it is used. The phenomenon of polysemy is caused by the variability of legal systems, as well as by the fact that different systems influence each other. An example of this phenomenon is the Latin expression "jus civile". In ancient times, this expression referred to the classical core of Roman law or the law that applied to Roman citizens, but later it was used in various senses among other things, it referred to Roman law in general, as well as to legal principles applicable between private individuals. Today the English term "civil law" refers both to continental law, based on Roman law, and to the main part of the private law of any state. Polysemy can be particularly deceptive in cross-border communication: the term "supreme court" usually refers to the body exercising supreme jurisdiction in a state or region, in New York State the "supreme court" is the ordinary trial court (Mattila, 2012). EU legislation is also a source of polysemy in legal language: The 
Union gives traditional legal terms a specific meaning, different from their meanings adopted in the Member States. Synonymy is also a phenomenon present in legal language, where several terms refer to the same concept. Examples of this in English are the terms "edge" and "confess", "act" and "deed", "will" and "testament" (Matilla, 2012, p. 31).

The literature often emphasises that there is no single, coherent and easily describable language of law and points to the coexistence of several different languages of law (Galdia, 2009). Some researchers distinguish within the boundaries of the language of law (legal language in the broad sense) the language of the first degree, i.e. the language of legal texts (language of legislation) and the language of the second degree, the metalanguage of law, with the help of which lawyers talk about law and comment on legal texts (language of lawyers). It is the differences between them make the language of law in general eludes unambiguous classifications. This distinction seems to have opened up new perspectives in the scientific study of the linguistic phenomenon in question (Gizbert-Studnicki, 1986).

The first of these languages is distinguished by the fact that provisions formulated therein, containing descriptive statements do not contain information about norms, but the norms themselves. We do not receive information from the legislator about an order or prohibition of certain behavior, but the prohibition or injunction itself. The second language is the language of legal doctrine, in which representatives of science and practitioners describe the language of legal texts. It is used to interpret regulations, and precisely defines the meaning of legal terms and phrases. Due to the service functions it performs in relation to the first-degree language, its vocabulary is much richer compared to that of the subject language (Gizbert-Studnicki, 2019). Both languages distinguished within the broadly understood language of law are not isolated from each other. On the contrary, there is a network of interconnectedness between them. The authors of normative acts, when creating a new law, draw from the metalanguage of law, while theorists and practitioners use terminology taken from the language of legal texts in their work. So there is mutual interference between them. Both languages necessarily correspond to each other, the development of one of them determines the development of the other. They are also connected by the social function they are to perform - both should contribute to raising the legal culture of society and make legal acts communicative (Gizbert-Studnicki, 1986).

The legal language described above appears complicated, often difficult to read and potentially problematic. One of the advocates of reforming the language of law is K. L. Bhatia. Bhatia emphasises that legal language 
should be characterised by simplicity, it should be free of expressions that are unclear, difficult to interpret or notoriously ambiguous, and there should be no place for metaphors. The model language is maximally precise, concise, clear and comprehensible, non-hermetic, accessible also to non-lawyers (Bhatia, 2010). “... plain legal language must be logical in its presentation that requires precision, consistency, conciseness, positive approach and use of familiar and concrete words" (Bhatia, 2010, p. 30). These demands apply as much to the language of legislation as to the language of lawyers, the language and meta-language of law.

An important feature of texts and statements formulated in the language of law is the presence in them of numerous definitions. A given term needs to be defined when it is ambiguous or not sharp, and limitation of its vagueness is needed, and also when its meaning is not commonly understood. It is worth emphasizing that creating definitions in law is an art that requires great skill, both linguistic and legal. The appearance of a definition in a legal text has important consequences - an expression, once defined, occurs within the text only in the sense given to it by the definition. (This does not preclude the term appearing with a different meaning in another legal text). The role of definition (and the process of defining) in legal language cannot be overestimated - it allows the elimination of ambiguity, makes the text precise, and contributes to its communicativeness (Patryas, 1997).

One of the essential features of a legal text, apart from communicativeness, is its adequacy, i.e. compliance of what the legal text proclaims with the actual intentions of the legislator. The way to achieve such adequacy is undoubtedly a pursuit of the highest possible precision or even unambiguity (Hiltunen, 2012). "Opposing themselves to the inherent vagueness of language, lawyers make many attempts at precision of expression. Their language essays precision by choice of particular words and phrases, and by devices of composition such as numbering, lettering, indexing, and even symbolic logic. (...) there is a recurrent choice of absolutes: all, none, perpetuity, never, unavoidable, last clear chance, unbroken, uniform, irrevocable, impossible, outright, wherever, whoever" (Mellinkoff, 2004, p. 22). However, the legislator does not always want to be precise - sometimes, noticing that the reality that is the subject of regulation is subject to rapid changes - and decides to include this variability in the text of the act by appropriately flexible formulation of some of its provisions (Mellinkoff, 2004).

Galdia, one of the founders of legal linguistics, considers speech acts in J. L. Austin's terms and discourse are the leading theoretical concepts of any reflection on legal language. He stresses that in a pragmatic approach 
to legal language, law appears as the result of discursive practices that are controlled by legal-linguistic speech acts. Legal language is identifiable in professional and non-professional discourses about law in which the meaning of law is constituted. The description of legal discourse is considered the last word in legal linguistics, as its primary task is to identify the characteristics of legal discourse, regardless of its form (Galdia, 2021). Galdia particularly emphasises the importance of legal linguistic operations that occur in legal discourse:

...legal linguistic operations such as legal argumentation or legal translation do not exist in a vacuum. They form bigger textual units and can be adequately understood within the boundaries of these superimposed units, such as legal discourse. The legal discourse is fundamental because all legal linguistic operations can be construed as contributions to it like bricks that are used for the construction of a house (Galdia, 2009, p. 240).

When legal language is understood in this way it means more than just legal terminology. It is important to conceive legal language as containing larger linguistic units - legally relevant speech acts. This applies also to legal translation. "Legal speech acts that form the legal discourse in one legal language are transformed there into equivalent legal speech acts of the target language" (p. 237). S. Šarčević has written about the importance of legal translation: "translations of legal texts lead to legal effects and may even induce peace or prompt a war" (2000, p. 1).

Unlike in the sciences, translation in law is not a simple transition from one language to another. In law, translation consists in transposing a message present in a given legal system into a message within another system. This is not an easy task - the language of law evolves and reflects the values of the society where it originated. This may apply to a translation of any text in the humanities, but in the case of translations of legal texts, the complication is much more serious. The legal language of a state differs from that of another state not only because law and language are genetically related and reflect, as the proponents of the historical school of law claim, the spirit of the nation; profound differences also exist between the legal systems of different states. Montesquieu was certainly right when he wrote that "it is a rare thing for the laws of one nation to be suitable for another." The legal systems of Germanic countries, the Anglo-Saxon common law, the systems of the former communist countries, as well as the system of Islamic law or the system of law of countries of the Far East are very different from each other and, therefore, their mutual contacts give rise to many problems (Agustyniak, Gąszczyk, 2010). "Legal translatabil- 
ity is a space of possibilities, an autonomous realm of 'cross-cultural events' within which the 'system-bound' legal concepts and notions deeply rooted in the language, history, and societal evolution of one country are transformed and integrated into the language of another, and as a result, stratified over the course of time" (Cheng, Sin, Wagner, 2016, p. 1).

These issues are explored by a relatively new discipline, jurislinguistics, which is a synthesis of law and linguistics, especially applied linguistics, and whose findings are used by both lawyers and linguists, as well as translators (Pieńkos, 1999). As one of its authors points out, legal linguistics is still paradigmatically a largely undefined or underdetermined field of knowledge (Galdia, 2021). The discipline is developed primarily by comparative and international lawyers - experts in international law, probably because in their work the language barrier is the greatest obstacle. An important impetus for its development is the deepening international integration within the European Union. Efforts to build a common legal framework while respecting the principle of cultural and legal distinctiveness require a careful comparison of the legal systems of the Member States, including individual standards, concepts, and terminology (Bhatia, Candlin, Allori, 2008).

Important side effects of the legal situation specific to the European context have been a great awareness by continental European linguists of the importance of the multicultural, multilingual studies and comparisons of legal discourses across cultures and the great importance given to the legal translation and the training of translators in this specific field (Bhatia, Candlin, Allori, 2008, p. 10).

An adept of legal linguistics, a translator of legal texts should combine a number of competences - a philologist, linguist, and lawyer. He should demonstrate competence in fluent knowledge of the native and foreign languages, knowledge of legal systems, as well as the socio-legal reality of the linguistic areas to which the translated texts relate. The essence of his work is the transfer of information from one legal system to another; such transfer is often problematic - it is difficult to adequately transfer the information expressed in the source language to the target language. When a specific expression of a legal language is used in a legal act, it must be understood in accordance with the meaning given to it in that language. The translator's work is often complicated by the fact that legal texts deal additionally with at least one field, so they are formulated in at least two specialised languages. Legal translation is based on the principle of maintaining the relationship of the content of the translation with the legal system of the source language 
and the specificity of the field to which the text refers. The essence of the translator's work is to catch the sense and find in the target language such a form that could convey the same sense, but in a way consistent with the target language system (Matulewska, Gortych, 2009).

A. Matulewska (2013a, 2013b) discusses the problems related to the incompatibility of the legal and juridical realities of different linguistic areas. She notes that Polish-English translators and translators of other language pairs, where one of the languages is the language used in more than one country as the language of legal communication, have to solve problems arising from the existence of terminological discrepancies within the same language used in different geographical areas.

The problem lies not only in the necessity to unify the terminology - due to the phenomenon of intertextuality present in the source text, the translator may face the challenge of rendering the terminological diversity resulting from its functioning in different legal contexts. The source text, which seems to be terminologically coherent, may require the translator to use several different equivalents for a seemingly single entity, a seemingly single designator occurring in the source language (...) the semantic field of a given term may be modified by the context, which is the intertext (translation mine) (2013b, p. 160).

The authors of monographs on legal linguistics give many examples of the problems faced by translators of legal texts. Here, dilemmas are caused by, inter alia, terms that have a different meaning in the language of law than in ordinary language, such as the English trial, action, advise, or represent. In the German-speaking area, the word Richter meaning judge can be expressed in French using the words judge or magistrat, but the latter term also has a broader meaning, including a prosecutor. With regard to criminal or civil procedure, the German and French laws have no equivalents for many of the legal institutions in that area. Similarly, in the area of state law and administrative law in different legal systems in the world that are based on different cultural foundations, there is often a significant problem with proper interpretation of a term or concept, or with finding an equivalent of a given legal institution (Matulewska, 2008, Pieńkos, 1999). Probably the most problematic in this aspect is private law, especially contract law; the existence of various national versions of contract law is a serious impediment to the development of cross-border commercial relations (Šarčević, 2010, Engberg, 2012). Theoretically, it is even conceivable that a given legal text cannot be translated into another language and the institutions and concepts of a given legal system may not have their equivalents in another system: 
(...) in spite of the growing efforts of the international community to guarantee greater and greater harmonization in legislation and procedures, the normative texts in use in the various contexts often show significant discrepancies in their formulation. This is due to the fact that legal terminology is so culture-bound (the reasons being at the same time historical, sociological, political and jurisprudential) that a satisfactory translation of all the legal terms of a text from one context to another is at times impossible (Gotti, 2008, p. 23).

The above-mentioned problems are one of the reasons why the idea of using Esperanto as the universal language of law nowadays has its enthusiasts. Esperanto as a legal language is promoted by the International Jurist Esperanto Association (IJEA), an international association of lawyers speakers and enthusiasts of Esperanto, working together with the World Esperanto Association. The association brings together lawyers-practitioners, representatives of doctrine and law students from all continents, and when it comes to the nationality profile, the most widely represented are Spaniards. In article 3 of the statute, the association defines its goals. They are mainly: strengthening solidarity among its members; using Esperanto practically and scientifically in all branches of law; improving legal terminology in Esperanto; making Esperanto visible in legal and non-legal circles through information and communication; acquiring members from as many countries as possible, bearing in mind the global representation of IJEA as an Esperanto legal association; pursuit of justice, legality, and respect for human rights and democracy, including in official national and international bodies. Other objectives of IJEA are to defend the rights, interests, prerogatives and immunities of all lawyers in the world and to contribute to access, knowledge, and enforcement, and the development of a global legal culture. Significantly, the statutes declare that the only official language of the association is the international language Esperanto (Internacia Jurista Esperanto-Asocio Statuto, 2017).

The IJEA spreads knowledge about Esperanto among lawyers and one of its methods is publishing: the association has, for example, published the Code of Hammurabi in Esperanto. IJEA is the publisher of the legal journal Jura Tribuno Internacia, which has been published since 1997. This journal proves that Esperanto can be an effective tool for communication between lawyers from different parts of the world ${ }^{2}$. The IJEA website features archival issues of the journal - reading them shows that the members of the association and the authors of the texts represent various areas of law. Articles on public international law and European law are the most numerous, but you can also find texts on environmental law, civil law and family 
law, or labor law. Some publications deal with the issues of human rights and constitutional law. In addition to analyses of current legal problems, the journal features memoirs devoted to eminent Esperantists. An important, permanent position are entries from the Esperanto legal dictionary - terms such as judgment, verdict, or usucaption have appeared here (Jura Tribuno Internacia).

The analysis of IJEA's activities and the content of Jura Tribuno Internacia shows that Esperanto is fully suited to the role of a metalanguage of law, the language of lawyers. It can be used to discuss various legal problems and issues, making it possible to conduct substantive discussions and reach conclusive solutions. Importantly, the texts published in the journal of Esperantist lawyers are not limited to selected areas of law - there are articles on many different legal disciplines. The publication of the entries of the Esperanto legal dictionary is an extremely important element of the activity of lawyers associated in the IJEA, constituting a tangible contribution to the development of the language of law.

There are branches of law that have been conceived as tools for cooperation between nations. International law and Esperanto have partially converging aims, so perhaps the idea of making Esperanto a tool for that law should be considered. English is often used as a universal language due to the cultural and technological superiority of the USA and the UK, but there are good reasons for Esperanto to replace it. International legal institutions, not wishing to favor any single language, use many other languages besides English as official languages, and their number is constantly increasing, which results in a huge number of translations and documents generated.

This is the situation of the European Union, where, in accordance with the principle of respect for the linguistic diversity of the Member States declared in its founding documents, the principle of equal authenticity of all language versions of a legal act has been introduced. This principle assumes that all versions of an EU legal act should be treated equally. This means that normative acts are prepared and published in as many as 24 languages, and all of them have the same binding force; Karin Luttermann describes this situation as "Language Babel of Brussels" (2009). (Theoretically, courts should, especially in difficult cases, compare all authentic texts of a legal act to determine its full content. However, this is a particularly difficult procedure, not applied in practice, because then judges should be expected to know all 24 official languages of the European Union as well as to know the legal reality of other countries). This principle often leads to a lack of coherence and inconsistency in EU directives (Gotti, Williams, 2010). 
In order to solve the above problem, various solutions have been proposed (Luttermann, 2009), including introducing a single common international legal language (Šarčević, 2013). S. Šarčević (2010) wonders to what extent lawyers, politicians and EU citizens are ready to adopt a new common language and a new legal culture that goes hand in hand with it. The researcher notes that skeptics could argue that this idea is contrary to the EU principle of respecting cultural and linguistic diversity, while the intention of the authors of this proposal is not to replace national languages and cultures, but to create a neutral meta-language which would inspire the creation of a new European culture and a universal European model of legal thinking. A new language and a new culture could coexist peacefully with national languages and cultures. The consequence of adopting a common international language could be the formation of a new European awareness and the consolidation of universal European values. The new pan-European language of law would be as inspiring for a legislation of united Europe as the reception of Roman law was inspiring for nineteenth century European legal systems.

Esperanto seems to be the right proposition here, which all member states could accept. Esperanto, as an artificial language system, is genetically precise and free from ambiguity, so it exhibits two of the most important universal features of the language of law. Esperanto is also a flexible system with a great word-formation potential, which will allow it to adapt smoothly to the changing social and legal reality. The above concept is not a new idea, it was put forward by a German representative in the 1950s during discussion about the shape of the future community. The adoption of this concept would involve the development of a legal dictionary in Esperanto, the creation of which would involve all member states. (The base for such a dictionary would be a dictionary created by the IJEA).

Esperanto's undoubted advantages include the fact that it is an easy-tolearn language: its grammar, unlike that of existing natural languages, can be mastered in a few days - for new, especially non-European, members of international legal organizations and institutions, this can be a significant convenience. Finally, the use of English as the main language may give the impression of favoring and promoting British values and culture and giving representatives of Anglo-Saxon countries a privileged position; it may also irritate the national ambitions of other members. The special value of the Esperanto language and culture is that they are not aggressive or oppressive; that is, they do not in any way lead to the domination, subjugation, or colonization of other culture (Grzybowski, 2017). 
Since the second half of the twentieth century, the dominance of English as a lingua franca has become overwhelming in all fields, including legal activities. Even if at the beginning of the third millennium other major European languages also play an important role as lingua franca in the legal field, e.g. French in Africa and the EU, the position of English remains dominant. Lawyers from different countries increasingly use English in all contexts of international communication, from lawyers' conferences to contracts between entrepreneurs (Cheng, Sin, \& Wagner, 2016). English has dethroned French, previously acting as the lingua franca of legal communication (Bhatia, 2010). In England itself, French was used as a legal language until the seventeenth century (Tiersma, 2012). The influence of French on legal English is evidenced by the presence of terms such as: "appeal", "attorney", "bailiff", "bar", "claim", "complaint", "counsel", "court", or "demurrer" (Bhatia, 2010, p. 8). Prior to the UK's accession to the EU, French was the sole official language of the European Coal and Steel Community and the European Economic Community and remained the most widely spoken language among the Community's partners for over 20 years; it was also the language of diplomacy. French started to lose its dominance as the main working language after the enlargement of the European Union in 1995, while a year later the use of English in the basic texts of the European Commission overtook the use of French. French has now largely been replaced by English as the first language in EU legal activity, with the exception of the European Court of Justice. The special status of English was strengthened by the fact that English was used in all negotiations with candidate countries (Kużelewska, 2020).

English is now a widely used language in the European Union, not only as one of the 24 official languages of the Member States, but also as the working language of EU institutions, political debates, and negotiations with partners outside the Union. More and more translations are being produced between legal English and other legal languages. This trend is particularly evident in contexts where English is used as a bridge, a language connecting two relatively minor languages, when direct translation between them is not possible. When translation from a minor continental legal language into a second minor continental language is done through English, it means that the message created within the civil law system and addressed to the audience within the second civil law system passes through the language developed within the common law system. Consequently, the danger of distortion of meaning is particularly high and translators must be particularly careful (Cheng, Sin, Wagner, 2016). 
However, the position of English as an international language of law has been seriously undermined by the exit of the United Kingdom from the EU structures. As E. Kużelewska predicts, Brexit will make the geopolitical importance of English diminish. Due to the fact that there are fewer native speakers of English in the EU today than speakers of, for example, Hungarian, Germany and France will try to increase their influence on EU language policy. The promotion of the other working languages of the EU, German and French, is likely to meet with opposition from the users of other languages, which opens up the possibility of a new discussion on the use of Esperanto as an international language of law.

During the Third World Esperanto Convention held in Great Britain, Zamenhof said:

We gather year after year, coming from all parts of the world, to feel the warmth resulting from our meeting and the enthusiasm for the idea that Esperanto contains... In the Esperanto world, there is (...) an inner idea, there is a green banner. Neutrality is a characteristic of all international conventions, but while at various congresses it is a mere matter of tactful behavior, for us, in fact, neutrality, or the objective to make international relations neutral, constitutes the whole content, the whole meaning of our work (translation mine) (Ziółkowska, 1959, p. 267).

The Esperantists' anthem, written by Zamenhof and sung during the annual congresses, proclaims: "On a neutral language basis / Understanding one another / The people will make in agreement - / One great family circle." (Ziółkowska, 1959, p. 269).

As one can see, Esperanto was never just a language; its ideas were not just limited to those of an artificial international language. The language was one of the tools aimed to contribute to the reconciliation of peoples in the world (Garvia, 2015). As Przemysław Wierzbowski, the chairman of the Esperanto Society of Białystok, pointed out, "Esperanto is not just a dry tool for communication, (...) it is a certain idea for a different world," and the Esperanto movement itself is nowadays "uniting people under common ideas." According to this Esperantist, the Esperanto movements are becoming more and more professional, cooperate with international organizations, and draw attention to various forms of discrimination in the modern world, conducting projects for refugees or sexual minorities, for example (Wierzbowski, 2019).

An argument for the use of Esperanto in international law is that the axiology adopted by Esperantists corresponds to the values of democratic societies, especially the idea of equality and social justice. One of the dis- 
tinctive features of the culture created by Esperantists is its opposition to intolerance and discrimination, which is important to many international legal organizations. Another assumption of Esperanto is the activation of societies based on social dialogue, which is important in the context of the numerous conflicts based on worldview and economics, the consequences of which are particularly painful to ethnic minorities (Grzybowski, 2017).

An important issue in the context of assessment of the usefulness of Esperanto for law and lawyers is whether Esperanto is really "alive" and whether it is developing at a pace appropriate to the pace of change in societies. The speakers and enthusiasts of that language claim that it is spoken by between 500,000 and two million people around the world, and they provide examples of small groups of people for whom Esperanto is their first language. Esperanto enthusiasts believe that it is a living language with great potential, but this belief is not universal. The linguist Tomasz Krzeszowski stated that Zamenhof's major mistake was to assume that since Esperanto was created on the basis of several widespread languages, it would be easy to learn for everyone. The creator of Esperanto did not take into account the fact that the elements he considered international were in fact European and so, for example, Esperanto is a rather difficult language to learn for Asians. The size of the community for which Esperanto is the first language is also questionable: according to experts, it is too small and does not form a homogeneous ethnic and cultural group, which leads to the lack of the cultural context that is natural for ethnic languages (Mizerski, Krzeszowski, 2007).

\section{Conclusion}

The question of whether Esperanto, as the most advanced and successfully implemented design of a common language for humankind, is suitable as a universal language of law is a question that cannot at present be answered conclusively. The use of Esperanto in the translation of legal texts from natural languages is undoubtedly problematic, but its use in international legal discussions and in the practice of international legal organizations and institutions seems to be quite realistic in the near future. Such use of Esperanto would be an ideal fulfilment of the ambitions of Ludwig Zamenhof and G. W. Leibniz (creator of the project of an artificial language of law much appreciated by Galdia) who believed that their implementation would help maintain world peace and bring closer the vision of a world without hunger and poverty. Everything depends on the 
openness of the governments of countries that are members of international organizations, the activity of the media in promoting Esperanto, and the determination of Esperanto speakers themselves. The latter recognize the promotion of Zamenhof's invention as the most important statutory goal of their organizations and they are extremely zealous in its realization thanks to them, much is being said and written about Esperanto. For the success of the idea of making Esperanto the international language of law, the activity of the IJEA could be crucial. It is important to intensify work on an Esperanto legal dictionary, as well as to expand the range and circle of authors and the volume of the Esperanto legal journal "Jura Tribuno Internacia". It is also advisable to change the frequency of publication of this periodical - currently it is an annual. Perhaps it would be worth making it a quarterly.

Certainly, the implementation of Esperanto in schools at all stages of education would be helpful in making it popular (this idea has a chance to be even partially fulfilled; for example, in Brazil there is currently a discussion on including teaching this language into the curriculum of secondary schools). Implementing this concept would require solving a number of organisational issues, e.g. the problem of educating Esperanto teachers it seems that graduates of interlinguistics are best prepared for this role. However, there are far too few of them - in Poland, the only academic centre where one can study interlingualism is the Adam Mickiewicz University in Poznań. The study includes classes in general and applied linguistics and the study of international languages, with a particular focus on Esperanto, dealing with its analysis, literature, and history, with a particular emphasis on intercultural communication. Among the possible specializations is the methodology of teaching Esperanto. Unfortunately, this course is unique there are only a few centres of this kind in the world, with Esperanto as the language of instruction. It would also be difficult to find suitably qualified legal translators of Esperanto today, as they would have to combine translation skills with legal knowledge. Equally problematic is the question of financing the teaching of Esperanto at different stages of education - ideally, the costs should be borne jointly by the state and local governments, perhaps with EU funding.

There is no doubt that Esperanto has a number of advantages over English, such as its ease of learning, its simple and exception-free grammar, and its neutrality, which is so strongly emphasized by Esperantists. At the time of the expansion of Asian countries and the related transformations on the international scene, these may be its greatest strength. The fact that Esperanto is deprived of a legal culture and local specificity is now an im- 
portant argument for making it a supranational legal language. The current political situation in Europe, especially the UK's departure from the EU, could help to realise this idea. The postulate of making Esperanto one of the official languages of the EU, which first appeared in the 1950s during discussions about the future shape of the community, has recently been revived in the European Parliament. Esperanto lawyers and all Esperanto enthusiasts in the EU should take advantage of the favourable political situation to put this postulate into practice.

\section{N O T E S}

${ }^{1}$ It is significant that this idea has gained the approval of some modern positivists, convinced that Leibnizian thought has found its expression in the achievements of modern mathematical logic, allowing, in their view, the expression of every sensible thesis of philosophy and the settlement of all philosophical feuds (Kołakowski, 1995).

2 The very concept of cooperation between lawyers representing different legal orders was born in 1906 in Geneva, during the world Esperanto Congress, when the "Internacia Societo de Esperantistaj Juristoj" was created.

\section{R E F E R E N C E S}

Agustyniak Ł., Gąszczyk R. (2010). Tłumaczenie nazw wybranych instytucji prawa cywilnego (w odniesieniu do terminologii common law) [Translation of names of selected institutions of civil law (with reference to common law terminology)]. Państwo i Prawo, 9, 70-82.

Bhatia K. L. (2010). Textbook on Legal Language and Legal Writing. New Delhi: Universal Law Publishing.

Bhatia V. K., Candlin Ch. N., Allori P. E. (eds). (2008). Language, Culture and the Law, The Formulation of Legal Concept across Systems and Cultures. Bern-Berlin: Peter Lang.

Cheng, L., Sin K. K., Wagner A. (eds) (2016). The Ashgate Handbook of Legal Translation. Law, Language and Communication. Farnham: Ashgate Publishing Company.

Draft resolution on establishing 2017 as the Year of Ludwik Zamenhof - the creator of the Esperanto language (2016) at: http://orka.sejm.gov.pl/Druki8ka.nsf/ Projekty/8-021-53-2016/\$file/8-021-53-2016.pdf.

Engberg, J. (2012). Word Meaning and the Problem of a Globalized Legal Order. In: P. M. Tiersma, L. M. Solan (eds), The Oxford Handbook of Language and Law, Oxford: Oxford University Press.

Forster P. G. (2012). The Esperanto movement. Hague, Paris, New York: De Gruyter Mouton. 
Galdia, M. (2021). Legal Constructs. Reflections on Legal-Linguistic Methodology. Poznań: Wydawnictwo Rys.

Galdia, M. (2009). Legal Linguistics. Frankfurt am Main: Peter Lang.

Garvia R. (2015). Esperanto and Its Rivals. The Struggle for an International Language. Philadelphia: University of Pennsylvania Press.

Gizbert-Studnicki T. (2019). Pisma wybrane. Prawo. Jezyk, normy, rozumowania [Selected papers. Law. Language, norms, reasoning]. Warsaw: Wolters Kluwer.

Gizbert-Studnicki T. (1987). Język prawny z perspektywy socjolingwistycznej [Legal language from a sociolinguistic perspective]. Zeszyty Naukowe Uniwersytetu Jagiellonskiego. Prace z nauk politycznych, 26. Warszawa-Kraków: PWN.

Gładziuk N. (2005). Druga Babel. Antynomie siedemnastowiecznej angielskiej myśli politycznej [Second Tower of Babel. Antinomies of the seventeenth-century English political thought]. Warsaw: Instytut Studiów Politycznych PAN.

Gotti M. (2008). The Formulation of Legal Concepts in Arbitration Normative Texts in a Multilingual, Multicultural Context. In: V. K. Bhatia, Ch. N. Candlin, P. E. Allori (eds), Language, Culture and the Law, The Formulation of Legal Concept across Systems and Cultures (pp. 23-46). Bern-Berlin: Peter Lang.

Gotti M., Williams Ch. (2010). Introduction. In: M. Gotti, Ch. Williams (eds), Legal Discourse across Languages and Cultures, Bern-Berlin: Peter Lang.

Grzybowski P.P. (2017). Opinia do wniosku Stowarzyszenia Europa-DemokracjaEsperanto o wpis jezzyka esperanto jako nośnika kultury esperanckiej na krajowa liste niematerialnego dziedzictwa kulturowego, sporzadzona na potrzeby Departamentu Ochrony Zabytków Ministerstwa Kultury i Dziedzictwa Narodowego [Opinion for the application of the Europe-Democracy-Esperanto Association to include Esperanto as the carrier of the Esperanto culture in the national list of intangible cultural heritage prepared for the Department of Monuments Preservation of the Ministry of Culture and National Heritage], at: https://repozytorium.ukw.edu.pl/bitstream/handle/item/4224/ Grzybowski_Opinia_do_wniosku_Stowarzyszenia_Europa-Demokracja-Espe ranto.pdf?sequence=1\&isAllowed=y (accessed on 15 October 2020).

Heinz A. (1978). Dzieje jezykoznawstwa w zarysie [An outline of the history of linguistics]. Warsaw: PWN.

Hiltunen R. (2012). Grammar and Structure of Legal Texts. In: P. M. Tiersma, L. M. Solan (eds), The Oxford Handbook of Language and Law, Oxford: Oxford University Press.

Internacia Jurista Esperanto-Asocio Statuto (2017). On: https://www.esperanto juro.org/statuto/ (25 October 2020).

Janton P. (1993). Esperanto. Language, Literature and Community. New York: SUNY Press. 
Jura Tribuno Internacia. On: https://www.esperantojuro.org/revuo/jura-tribunointernacia/ (25 October 2020).

Jura Vortaro. On: https://www.esperantojuro.org/jura-vortaro/juraj-vortaroj/ (25 October 2020).

Jurkowski M. (1986). Od Wieży Babel do języka kosmitów [From the Tower of Babel to the language of aliens]. Białystok: Krajowa Agencja Wydawnicza.

Klemensiewicz Z. (1966). Czy warto zajmować się esperantem? [Is it worth dealing with Esperanto], Poradnik Jezzykowy, 8, 378-380.

Klemensiewicz Z. (1963). Przedmowa [Preface]. In: M. Sygnarski (ed.), Podręcznik jezyka esperanto [Esperanto handbook]. Warsaw: Wiedza Powszechna.

Kołakowski L. (1955). Przedmowa [Preface]. In: G.W. Leibniz, Nowe rozważania dotyczace rozumu ludzkiego [New essays on human understanding]. Warsaw: PWN.

Kopania J. (1988). Funkcje poznawcze Descartesa teorii idei [Cognitive functions of Descartes' theory of ideas]. Białystok: Dział Wydawnictw Filii Uniwersytetu Warszawskiego.

Krzyżak K. (2011). Esperanto w kościele katolickim. On: http://web.archive.org/ web/20161113043655/http://netformator.pl/publicystyka/rozne/sprawyspoleczne/1792-esperanto-w-kociele-katolickim- (30 November 2020).

Kużelewska E. (2020). Quo Vadis English? The Post-Brexit Position of English as a Working Language of the EU. International Journal for the Semiotics of Law, 11.

Luttermann, K. (2009). Multilingualism in the European Union. Status quo and perspectives: The reference language model. In: G. Grewendorf, M. Rathert, Formal Linguistics and Law. Berlin-New York: Mouton de Gruyter, 315-338.

Mattila H. E. S. (2006). Comparative Legal Linguistics. Hampshire: Ashgate.

Mattila H. E. S. (2012). Legal Vocabulary. In: P. M. Tiersma, L. M. Solan (eds), The Oxford Handbook of Language and Law. Oxford: Oxford University Press.

Matulewska A. (2008). Jakość przekładu prawniczego a cechy języka prawa [The quality of legal translation and the features of the language of law]. In: Język, Komunikacja, Informacja (53-63). Poznań: Wydawnictwo SORUS.

Matulewska, A. (2013). Legilinguistic Translatology. A Parametric Approach to Legal Translation. Linguistic Insights vol. 171. Bern: Peter Lang.

Matulewska, A. (2013). Polska terminologia prawa upadłościowego w kontekście. Przekład terminu zarządca na język angielski [Polish insolvency law terminology in translation into English. A case study of the term zarzadca]. Comparative Legilinguistics 13, 159-174.

Matulewska, A., Gortych K. (2009). Translacyjne problemy wyrażania modalności deontycznej w tekstach aktów normatywnych w języku polskim, angielskim i greckim. In: A. Mróz, A. Niewiadomski, M. Pawelec (eds). Prawo i język. Warsaw: Uniwersytet Warszawski, 65-78. 
Marciszewski W. (2002). Logika. Rachunek predykatów [Logic. Predicate calculus]. On: http://www.calculemus.org/lect/L-I-MNS/03/lim03.pdf (30 November 2020).

Mizerski S., Krzeszowski T. P. (2007). Słowne uniwersum. Człowiek w klatce języka [Verbal universum. Man in the language cage]. Polityka. Niezbędnik Inteligenta, 12.

Okrent E. (2010). In the Land of Invented Languages. New York: Random House. Patryas W. (1997). Definiowanie pojęć prawnych [Defining legal concepts]. Poznań: Wydawnictwo Naukowe UAM.

Pieńkos J. (1999). Podstawy juryslingwistyki. Język w prawie. Prawo w języku [Basic tenets of jurislinguistics. Language in law. Law in language]. Warsaw: Oficyna Wydawnicza Muza SA.

Romaniuk Z., Wiśniewski T. (2009). Zaczęło się na Zielonej. O Ludwiku Zamenhofie, jego rodzinie i początkach esperanta. Łódź: Dom Wydawniczy Księży Młyn.

Šarčević S. (2010). Creating a Pan-European Legal Language. In: M. Gotti, Ch. Williams (eds), Legal Discourse across Languages and Cultures (23-50). Bern-Berlin: Peter Lang.

Šarčević S. (2013). Multilingual Lawmaking and Legal (Un)Certainty in the European Union, The International Journal of Law, Language $\&$ Discourse, 8.

Šarčević S. (2000). New Approach to Legal Translation. Hague, London, Boston: Kluwer Law International.

Stillman R.E. (1995). The New Philosophy and Universal Languages in SeventeenthCentury England. London: Bucknell University Press.

Święczkowska H. (1998). Harmonia linguarum. Język i jego funkcje w filozofii Leibniza [Harmonia lingarum. Language and its functions in Leibniz's philosophy]. Białystok: Wydawnictwo Uniwersytetu w Białymstoku.

Święczkowska H. (2016). Language as a mirror of world order. Białystok: Wydawnictwo Uniwersytetu w Białymstoku.

Święczkowska H. (2002). "W poszukiwaniu tradycji" Leibnizjański projekt języka uniwersalnego ["In search of tradition." Leibniz's design of a universal language]. Białostockie Archiwum Językowe, 2, 197-225.

Tiersma P. M. (2012). A History of the Languages of Law. In: P. M. Tiersma, L. M. Solan (eds), The Oxford Handbook of Language and Law. Oxford: Oxford University Press.

Tonkin H. (ed.) (1997). Esperanto, interlinguistics and planned languages. Lanham, New York, Oxford: University Press of America.

Vasoli C. (1996). Encyklopedyzm w XVII wieku [Encyclopedism of the 17th century]. Warsaw: Wydawnictwo IFiS PAN.

Wierzbowski P. (2019). On: https://www.wnp.pl/parlamentarny/spoleczenstwo/ 160-lat-temu-urodzil-sie-ludwik-zamenhof-tworca-jezyka-esperanto, 46301. html (30 November 2020). 
Włodarczyk W. (1964). Esperanto? Wypowiedzi wybitnych polskich intelektualistów [Esperanto? Statements of outstanding Polish intellectuals]. Warsaw: Polski Związek Esperantystów.

Woleński J. (1967). Język prawny w świetle współczesnych metod analizy semantycznej [Legal language in the light of modern methods of semantic analysis]. Zeszyty Naukowe Uniwersytetu Jagiellońskiego. Prace Prawnicze, 31, 141145.

Ziółkowska M. (1959). Doktor Esperanto [Doctor Esperanto]. Warsaw: Wiedza Powszechna.

Żytyński J. (1987). Esperanto i esperantyści [Esperanto and Esperantists]. Warsaw: Wiedza Powszechna. 